\title{
IN QUEST FOR THE ULTIMATELY SUSTAINABLE BUSINESS MODEL
}

\author{
Agnieszka Kabalska ${ }^{1}$ \\ AGH University of Science and Technology in Krakow \\ Faculty of Management, Department of Social Capital and Organizational Management
}

\begin{abstract}
The sustainable business model (SBM) concept emerged as one of the most compelling research topics in contemporary management. The multifariousness of discussion areas and problems related to creating, implementing, and modifying SMBs offers great research potential. The aim of the article is to present an SBM's example that is ultimate, which means that it is sustainable in all three dimensions, i.e., in the technological, social, and environmental context, by applying innovations corresponding to these categories (technological, social, and organizational). Particular attention was paid to the discussion on SBM archetypes and a framework describing SBM key features that served as points of reference for further investigations. The paper comprises two major parts; the introduction of the sustainable business model concept is followed by research results. The theoretical part includes a presentation of the most important SBM definitions discussed in the managerial literature. In the second empirical part, based on secondary sources, an illustrative case study of an ultimately sustainable business model (USBM) was developed and discussed.
\end{abstract}

Keywords: business models, sustainable business model, sustainable value

DOI: $10.17512 /$ znpcz.2021.3.03

\section{Introduction}

The concept of the sustainable business model (SBM) is the topic of discussion in numerous scientific articles (e.g., Bocken et al. 2014; Geissdoerfer, Vladimirova, Evans 2018), books (e.g. Aagaard 2019), conferences (e.g. annual conference on New Business Models), or special issues of well-recognized scientific journals (e.g. 2019 Sustainability's "SBMs and Common Goods"). The plethora of research topics is immense, and their presentation is beyond the scope of this article. However, the reason for the growing popularity of the concept might lie in SBMs' fundamental impact on the company's long-term relevance, good public image, and its profitability (Agwu, Bessant 2020, pp. 1-18).

Entities, striving to keep up with the challenges of modern markets, face the difficult challenge of transforming their business models towards greater sustainability. Hence, an interesting dilemma is to take a step further considering the following question: is there a business model that is sustainable in every dimension, i.e., at the same time is influenced by technological, social or organizational innovations? The research question corresponds to the purpose of this article, which is to identify and

\footnotetext{
${ }^{1}$ Agnieszka Kabalska, PhD, akabalska@zarz.agh.edu.pl, ORCID: 0000-0002-9646-3469
} 
describe the ultimately sustainable business model (USBM) in Polish economic conditions. The article consists of two major parts, i.e., the theoretical introduction to the issue and the most important definitions of SBM, and the empirical part which, using the illustrative case study method, presents a model that was successfully developed in Poland.

The paper has both theoretical and practical value. The article corresponds to the topical discussion on the SBMs issues, the features characterizing such models, and the search for new approaches to SBMs archetypes. The practical value results from the specificity of the described case, which, at the same time, combines three dimensions of innovation in terms of technology, society, and organization, thus creating economic, social, and environmental values. The selected example of the ultimately sustainable business model could also be an important inspiration for practitioners looking for new ideas and directions to change their business models towards greater sustainability.

\section{The Sustainable Business Model concept}

In a very broad context, SBMs are perceived as business models that contribute to business responsibility (Stubbs, Cocklin 2008, pp. 103-127) in terms of competitive advantage creation. It is obtained through the value that is beneficial for the company and its stakeholders, the society at large, and the environment (Ludeke-Freund 2010, pp. 1-28). SBMs are believed to coincide with the perspective of global markets by considering the development of industrialized countries and the necessity of establishing more sustainable products and services (Garetti, Taisch 2012, pp. 83-104). Importantly, SBMs could be perceived through the value perspective: value proposition (products and services offered in the market), creation and delivery (resources, activities, and competencies employed to create a product and/or service and deliver them in the market), and capture (revenues, costs, and rent distribution provided by the value proposition) (Schaltegger, Hansen, Ludeke-Freund 2016, pp. 3-10). Thus, in SBM, sustainability is a fundamental and integral part of the value proposition and value creation logic, offering value to the customer, society, and the environment (Abdelkafi, Tauscher 2016, pp. 74-96).

Similarly, SBM could be defined as an abbreviated representation of the components, relationships between them, and the stakeholders' transactions embraced by the entity to create, deliver, exchange, and capture sustainable value for and with its stakeholders (Geissdoerfer, Bocken, Hultink 2016, pp. 1218-1232). Hence, the sustainable value could be understood as a promise of benefits (in the long- and shortterm) (Patala et al. 2016, pp. 144-156), translated into economic, social, and environmental value forms (Evans et al. 2017, pp. 597-608). In this approach, the economic element refers to cost savings, profits, investment returns, and long-term viability; the social value appears as people's wellbeing, secure livelihoods, and communities' development. Finally, the environmental value complied with the counteraction or reduction of negative impacts and positive green contributions. Considering all these preconditions and functions, SBMs could also be defined as 
$\mathrm{BM}$ that is based on a long-term perspective of proactive multi-stakeholder management and creating value (in terms of monetary and non-monetary forms) for various stakeholders (Geissdoerfer, Vladimirova, Evans 2018, pp. 403-404).

All things considered, according to F. Goni and co-authors (2020, pp. 889-897), SBM should be characterized by three features that are unique for the concept and serve as differentiators from the "conventional" business models:

1. SBM aims to simultaneously create economic, social, and environmental value,

2. Unlike "traditional" BMs, SBMs pay attention to noneconomic value viewpoints (social and environmental ones),

3. SBMs also regard the destructed and uncaptured value.

Furthermore, F. Goni and co-authors, based on a comprehensive literature review, developed the conceptual framework for the nine key features constituting SBMs. The reference scheme included sustainability footing, circular economy, core, and organizational values, value creation, value chain, performance management, stakeholder engagement, and information technology (Figure 1).

Key Features of Sustainable Business Model

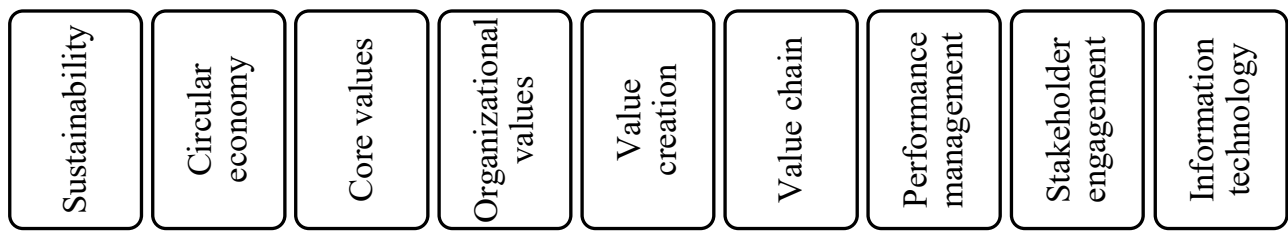

Figure 1. Key features of the Sustainable Business Model

Source: Author's evaluation based on F. Goni et al. (2020, pp. 889-897)

On that basis, sustainability in the SBM research could be interpreted as a strategic business answer to the environmental, social, and economic facets of business operations (ibidem). Similarly, a circular economy aims to reduce waste and manage resources adequately, seeking new approaches to providing value to stakeholders (i.e., by collaboration), better resource utilization (or prioritizing regenerative resources, reusing elements, or using waste as a new resource), and creation of economic value (business model re-design). In terms of SBM analysis, the entity's core values could include, among others, loyalty, reliability, loyalty, commitment, creativity, respect, or dedication. The following aspects, organizational values, are represented by safety (employee, public, environmental), profitability, responsibility, and striving for results. Key features of general value creation include financial, manufactured, intellectual, human, social, and environmental aspects. Then, a value chain, defined by M.E. Porter (1985) as a series of company's activities that are conducted to create products or provide services to the market, should be understood through the lenses of resources, suppliers, customers, and primary and support activities. Performance measurement could address various aspects, which might be referred to as service, business management, quality, productivity, and efficiency. 
Partnerships, participation, consultation, and communication are the key features of stakeholder engagement. Finally, information technologies are linked to hardware and software providing technologies, methods, and data management tools, leading to better data processing and applications (Goni et al. 2020).

One of the most important analyses in the SBM research was published by N. Bocken et al. (2014, pp. 42-56). Their dominant orientation towards innovation in SBMs allowed the recognition of eight SBM archetypes related to technological, social, and organizational innovations (Table 1). The fundamental aim of such categorization was to introduce and explain different mechanisms for sustainability delivery. The technological group retained archetypes with an orientation on technological innovation (e.g., new manufacturing solutions), then, the next category gathered archetypes oriented towards social innovation (e.g. shaping new customer behaviors), and the last category represented archetypes focused on innovations in organizations (e.g. collaborative approaches).

Table 1. Archetypes of the Sustainable Business Model

\begin{tabular}{|c|c|c|}
\hline \multicolumn{2}{|c|}{$\begin{array}{l}\text { SBM Innovation Category } \\
\text { \& Archetype }\end{array}$} & The key presumptions \\
\hline \multirow{3}{*}{ 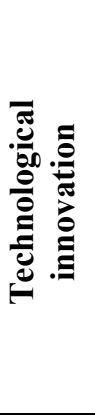 } & $\begin{array}{l}\text { Maximize material } \\
\text { and energy efficiency }\end{array}$ & $\begin{array}{l}\text { Limited utilization of resources, generating less waste, } \\
\text { lower emissions, and pollution. }\end{array}$ \\
\hline & $\begin{array}{l}\text { Create value from } \\
\text { waste }\end{array}$ & $\begin{array}{l}\text { Changing streams of waste into a useful and valuable } \\
\text { input with different production and better exploitation } \\
\text { of underutilized capacity. }\end{array}$ \\
\hline & $\begin{array}{l}\text { Substitute with } \\
\text { renewables and } \\
\text { natural processes }\end{array}$ & $\begin{array}{l}\text { Reduction of environmental impacts and better } \\
\text { business resilience are obtained by resolving the } \\
\text { constraints of resources (limits of non-renewable } \\
\text { resources). }\end{array}$ \\
\hline \multirow{3}{*}{ 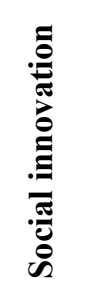 } & $\begin{array}{l}\text { Deliver functionality } \\
\text { rather than ownership }\end{array}$ & $\begin{array}{l}\text { Provision of services satisfying the customer's needs } \\
\text { simultaneously without owning physical products. }\end{array}$ \\
\hline & $\begin{array}{l}\text { Adopt a stewardship } \\
\text { role }\end{array}$ & $\begin{array}{l}\text { Active stakeholders' engagement to ensure their } \\
\text { long-term health and general well-being. }\end{array}$ \\
\hline & Encourage sufficiency & $\begin{array}{l}\text { Solutions that actively search for solutions of consump- } \\
\text { tion and production reduction. }\end{array}$ \\
\hline \multirow{2}{*}{ 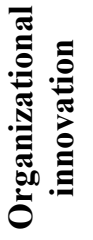 } & $\begin{array}{l}\text { Repurpose for } \\
\text { society/environment }\end{array}$ & $\begin{array}{l}\text { Social and environmental values are the key benefits, } \\
\text { rather than strictly economical ones. Close integration } \\
\text { between the company and its stakeholders is underlined. }\end{array}$ \\
\hline & $\begin{array}{l}\text { Develop scale-up } \\
\quad \text { solutions }\end{array}$ & $\begin{array}{l}\text { SBM aims to deliver large-scale, sustainable solutions } \\
\text { with benefit maximization (stakeholders, environment). }\end{array}$ \\
\hline
\end{tabular}

Source: Author's evaluation based on N. Bocken et al. (2014, pp. 42-56) 
The framework developed by N. Bocken and co-authors has inspired the further research of many other authors interested in exploring SBMs in various contexts and sectors, e.g., describing SBMs archetypes for the banking industry (Yip, Bocken 2018, pp. 150-169), or in the agricultural sector (Barth et al. 2021, pp. 1-10). In the Polish managerial literature, the research of SBMs is still insufficient (includes, among others, the publication by O. Seroka-Stolka and co-authors, 2017, pp. 116-125). This motivated further research on a fully sustainable BM (USBM), conducted on the example of an entity operating in Poland.

\section{Research method}

The literature review allowed us to find an inspiring gap in scientific considerations on BMs that are fully sustainable. Taking into account the selected definitions of the SBM concept (i.e., a business model creating and delivering value to the company, its stakeholders, and the natural environment, respectively: economic, social, and environmental context), in the article, various features describing SBMs and the aspects of shaping the SBMs archetype categories were analyzed. It was concluded that the ultimately sustainable business model (USBM) is a BM, where economic, social, and environmental value is created by simultaneously introducing technical, social, and ecological innovations.

The course of the research process is illustrated in the diagram below (Figure 2).

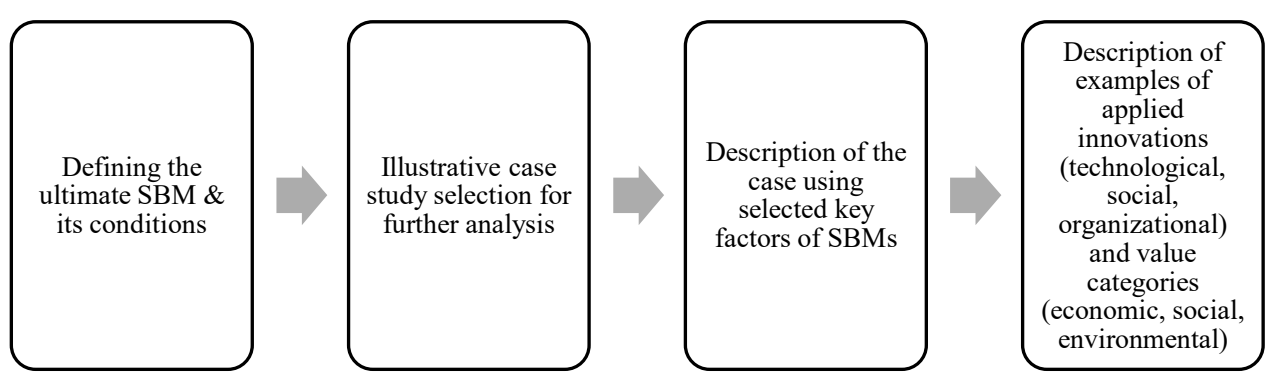

Figure 2. Research process

Source: Author's evaluation

The inspiration for a case study selection was an article published in March 2020 in the e-issue of Puls Biznesu (the outbreak of the COVID-19 pandemic), where the case of the "Ubrania do Oddania" initiative was discussed. Additionally, the author utilized her observations and dilemmas related to door-to-door charity pick-ups in Poland.

To add realism and in-depth background to SBMs, the chosen research method was an illustrative case study. Such a method depicts one or more circumstances to explain the situation, describes the phenomenon: what is happening to it, and why, and are in-depth and rich in context but still understandable (Hayes, Kyer, Weber 2015 , p. 8). In other words, illustrative case studies are written in detail and aim to provide descriptive details about the environment, participants, and other relevant 
information. The choice of this research method was also dictated by the possibility of using a variety of source materials, including reports, netographic content, and own observations. Statements regarding selected issues and a wider discussion were also supplemented with quotes from interviews with the founders of the company published in the media.

SBM Key Features by F. Goni and co-authors (2020) were used to implicitly describe the most important characteristics of this SBM. In addition, in a further part of the paper, the concept of SBMs archetypes by N. Bocken et al. (2014) was used as well.

\section{Research results and discussion}

"Ubrania do Oddania" (UdO) is an initiative established in 2017 to create a fully circular market of second-hand clothes in Poland by consistently implementing the idea and cooperating with various stakeholders (https://www.pb.pl/, 2020). Simply speaking, UdO turns unnecessary clothes into financial donations, which go to the NGOs that cooperate with the entity. Thus, the company gradually develops its fundraising platform by innovatively combining collecting preowned clothing with offering financial support for charities. The start-up also aims to grow social sustainability awareness by introducing new solutions for clothing companies, the fast fashion industry, and local governments.

The company's core values are transparency and tangible assistance (https://www.ubraniadooddania.pl/, 2017). UdO has been awarded several times for their pro-ecological activities and education, winning, among others, 1st place in the Zero Waste Contest in the "sustainable company of 2021" category. Currently, it also develops sustainability tools for fashion brands and assists in collecting clothes for local governments, serving as an advisor. The company's stakeholders include the founders, customers (contributors), business partners (courier company), associations, NGOs (a diverse group, chosen by the contributors), local governments, the society as a whole, and the natural environment.

The received (donated) items are sorted and recirculated following the principles of the circular economy. What is important, a proprietary sorting method (Clear Sorting) was developed, allowing to build a 100\%-circular Polish company that collects clothes, then processes the obtained items, and then re-circulates them in the country. Thanks to this, UdO contributes to the circular economy, cooperating with various second-hand stores, and currently, also working on launching its own second-hand circular network (https://www.ubraniadooddania.pl/, 2017). A simplified diagram presenting the company's value chain is shown in Figure 3.

As presented in Figure 3, the UdO value chain is an altered so-called modern value chain in which, contrary to the "traditional" proposal by M.E. Porter, the customers are centered at the beginning of the chain - they are not passive recipients of the value created by the company, but are active creators initializing the whole process. They donate the items and select the charity that they want to (in)directly support. 


\begin{tabular}{|c|c|c|c|c|c|}
\hline Contributor & & UdO/NGOs & UdO & UdO & Stakeholder \\
\hline \begin{tabular}{|l} 
The customer \\
packs their \\
undamaged \\
clothes \\
(in good \\
condition, \\
suitable for \\
use by \\
another \\
person) in \\
a recycled \\
cardboard \\
box.
\end{tabular} & $\begin{array}{l}\text { - The courier } \\
\text { picks up the } \\
\text { box on the } \\
\text { day and place } \\
\text { chosen by the } \\
\text { customer, } \\
\text { then } \\
\text { transports it to } \\
\text { the UdO 's } \\
\text { warehouse. }\end{array}$ & \begin{tabular}{|c|} 
Each package \\
is weighed \\
and its weight \\
is converted \\
into a \\
financial \\
donation to \\
a charity \\
organization \\
chosen by the \\
customer \\
(1 kg = PLN \\
1 rule is \\
applied).
\end{tabular} & $\begin{array}{l}\text { - The box is } \\
\text { opened, item } \\
\text { are sorted int } \\
\text { one of the } 50 \\
\text { categories. }\end{array}$ & $\begin{array}{l}- \text { Categorized } \\
\text { items are } \\
\text { prepared for } \\
\text { further sale } \\
\text { and } \\
\text { re-circulated } \\
\text { in line with } \\
\text { the principles } \\
\text { of the circular } \\
\text { economy. }\end{array}$ & \begin{tabular}{|l} 
- The customer \\
perceives the \\
co-created \\
value; there is \\
a closed loop \\
of second \\
hand clothing \\
in Poland \\
(value for the \\
environment).
\end{tabular} \\
\hline
\end{tabular}

Figure 3. UdO's value chain

Source: Author's evaluation

Table 2 presents a collective summary of dimensions and examples of various value categories within the analyzed business model and three categories of innovation related to these dimensions. For this purpose, as a supplement to own conclusions, the table contains excerpts from the interviews with the founders of the UdO that were published online.

The conducted research proved the diversity and complexity of the value creation processes in the analyzed SBM, as well as the diversity of the categories of this value and various types of innovations in the business model of UdO.

Although due to the very limited possibilities of presentation, only selected examples relating to the SBMs complexity were analyzed, the following conclusions could be proposed:

1. The most important observation is that a single SBM could be fully sustainable (thus, the USBM could be designed and implemented in real-life conditions).

2. Each of the innovation categories discussed in Table 2 has beneficial effects on the economic situation of the company, the welfare of society, and the state of the natural environment.

3. The use of the Key Features of SBM model developed by F. Goni et al. (2020) made it possible to identify a wide range of UdO's stakeholders and to trace the company's value chain in detail thereby defining a value chain that represents sustainable value co-creation, multivariate commitment, and palpable sustainability.

4. The discussed SBM engages various stakeholders and is based on cooperation, commitment, and balanced creation, delivery, and capture of value in different dimensions.

5. Based on the research results, it is concluded that the discussed attitudes and actions in the UdO business model correspond to the archetypes described by N. Bocken and co-authors (2014). For example, the archetype "Adopt a stewardship role" presumption could be readily found in the UdO model, which could also serve as valuable inspiration for other entities looking for their ideas for creating value in a broad context. 
Table 2. SBM of "Ubrania do Oddania" - value and innovation categories with respective examples

\begin{tabular}{|c|c|c|c|}
\hline \multirow{2}{*}{$\begin{array}{c}\text { Innovation's category with } \\
\text { argumentation }\end{array}$} & \multicolumn{3}{|c|}{ The category of value context } \\
\hline & Economic & Social & Environmental \\
\hline $\begin{array}{l}\text { Technological Innovation } \\
\text { "Clear Sorting method is based on } \\
\text { obtaining high-quality second-hand } \\
\text { textiles. It streamlines the sorting } \\
\text { process and makes it possible to } \\
\text { distinguish specific categories of } \\
\text { clothes, also by brand. The quality } \\
\text { of the collected clothes that go to } \\
\text { second-hand stores increases by } \\
\text { over } 95 \text { percent. Clothes are recy- } \\
\text { cled without any processing" } \\
\text { (https://www.green-news.pl/, 2021). }\end{array}$ & $\begin{array}{l}\text { Efficiency and } \\
\text { effectiveness of } \\
\text { the Clear Sorting } \\
\text { method, resulting } \\
\text { in reduced time } \\
\text { and lower re- } \\
\text { source consump- } \\
\text { tion (time, } \\
\text { energy). }\end{array}$ & $\begin{array}{l}\text { Items do- } \\
\text { nated by con- } \\
\text { tributors are } \\
\text { sold quickly } \\
\text { and accu- } \\
\text { rately; profits } \\
\text { go to those in } \\
\text { need (sense } \\
\text { of involve- } \\
\text { ment). }\end{array}$ & $\begin{array}{l}\text { Preservation of } \\
\text { natural resources } \\
\text { (fast and effective } \\
\text { processes). }\end{array}$ \\
\hline $\begin{array}{l}\text { Social Innovation } \\
\text { "We do not conduct marketing ac- } \\
\text { tivities [...] we haven't spent any } \\
\text { money on marketing. [...] we were } \\
\text { aware that the second-hand clothing } \\
\text { industry needs credibility and trans- } \\
\text { parency and we knew how to do it. } \\
\text { [...] We regularly conduct educa- } \\
\text { tional activities on our social media. } \\
\text { It is a great force today [...] I am } \\
\text { happy that our knowledge sharing } \\
\text { is noticed and that we can contrib- } \\
\text { ute to changing consumer behavior } \\
\text { and encourage the use of secondary } \\
\text { circulation" } \\
\text { (https://marketingibiznes.pl/... } \\
\text { 2021). }\end{array}$ & $\begin{array}{l}\text { Expanding the } \\
\text { pool of contribu- } \\
\text { tors involved al- } \\
\text { lows for generat- } \\
\text { ing, increasing } \\
\text { profits, growing } \\
\text { popularity, and } \\
\text { gaining potential } \\
\text { investors inter- } \\
\text { ested in coopera- } \\
\text { tion. }\end{array}$ & $\begin{array}{l}\text { The UdO's } \\
\text { growing pop- } \\
\text { ularity would } \\
\text { encourage } \\
\text { people to do- } \\
\text { nate their } \\
\text { clothes and } \\
\text { thus generate } \\
\text { support for } \\
\text { more NGOs. }\end{array}$ & $\begin{array}{l}\text { Non-marketing } \\
\text { policy; the growing } \\
\text { popularity of the } \\
\text { circular economy } \\
\text { among Poles would } \\
\text { result in their } \\
\text { greater consumer } \\
\text { awareness, reduc- } \\
\text { tion of purchases, } \\
\text { and thus environ- } \\
\text { mental benefits } \\
\text { (preventing over- } \\
\text { production and } \\
\text { overconsumption, } \\
\text { limiting the nega- } \\
\text { tive impact of the } \\
\text { clothing industry on } \\
\text { the environment). }\end{array}$ \\
\hline $\begin{array}{l}\text { Organizational Innovation } \\
\text { "UdO is the first in Poland that al- } \\
\text { lows charity organizations to collect } \\
\text { money without having to spend } \\
\text { even zloty by both the organiza- } \\
\text { tions themselves and their donors! } \\
\text { [...] For each } 1 \text { kg of clothes do- } \\
\text { nated by the contributor, PLN } 1 \\
\text { will be transferred to the account of } \\
\text { a charity chosen by him. It is so } \\
\text { now, and it will always be so" } \\
\text { (UdO LinkedIn profile: } \\
\text { https://pl.linkedin.com/...). }\end{array}$ & $\begin{array}{l}\text { Such a model of } \\
\text { operation is eco- } \\
\text { nomically bene- } \\
\text { ficial for all } \\
\text { stakeholders in- } \\
\text { volved (the com- } \\
\text { pany generates } \\
\text { revenue, partners } \\
\text { earn from con- } \\
\text { tracts for the } \\
\text { transport of par- } \\
\text { cels, NGOs re- } \\
\text { ceive financial } \\
\text { support, and con- } \\
\text { tributors do not } \\
\text { incur costs). }\end{array}$ & $\begin{array}{l}\text { New ap- } \\
\text { proaches to } \\
\text { partnership in } \\
\text { value co-cre- } \\
\text { ation, good } \\
\text { stakeholder } \\
\text { engagement, } \\
\text { and open- } \\
\text { ness. }\end{array}$ & $\begin{array}{l}\text { The possible repeat- } \\
\text { ability of such a } \\
\text { model would allow } \\
\text { fighting wastage } \\
\text { and support similar } \\
\text { initiatives on a } \\
\text { larger scale (closed } \\
\text { loop, reduced con- } \\
\text { sumption of raw } \\
\text { materials). }\end{array}$ \\
\hline
\end{tabular}

Source: Author's evaluation based on the given sources 
The forward-looking activities and expected development declared by the UdO allow us to predict that further changes would occur in this SBM (improvement, engaging new stakeholders, intensifying the value created), which would not pose a threat to the potential negative consequences of the intensification of activities, but would rather strengthen the comprehensiveness and sustainability of this business model.

\section{Conclusions}

The concept of a sustainable business model is dynamically gaining in importance and popularity in management sciences and economic practice. The conducted research has shown a plethora of scientific discussions, such as defining the concept of sustainable business models (e.g., Geissdoerfer, Bocken, Hultink 2016), sustainable value (e.g. Schaltegger, Hansen, Ludeke-Freund 2016), searching for reference features of SBMs (e.g. Goni et al. 2020) or defining archetypes of sustainable business models (Bocken et al. 2014).

It turns out that the entities operating in modern markets actively and with a significant commitment adopt the presumptions of a sustainable business model, as a result of which they look for new approaches and ideas for market challenges. Growing competition, appreciation of innovation, changing stakeholders' expectations, or the need to protect the natural environment could serve as important examples of these challenges. For this reason, the search for a business model that combines all these aspects has become a necessary and interesting topic.

The article presents the so-called USBM, recognized as a business model in which economic, social, and environmental value is created by simultaneously applying technical, social, and ecological innovations. The paper presents the example of the Polish company "Ubrania do Oddania", a company that appreciates new ideas, attitudes of commitment, inclusion in value co-creation, cooperation, and respect for the well-being of the environment as the overarching goal that affects all stakeholders. The analyzed case could serve as an inspiration for Polish business owners who intend to modify their business models towards greater sustainability or for managers seeking new, inspiring business ideas.

The technological (Clear Sorting method), social (co-creation of value and increasing public awareness), and organizational innovations (the first entity in Poland that, based on contributors' decisions, allows them to decide where the financial support should be directed) were presented. The discussion also includes examples of the economic, social, and environmental benefits of these innovations.

Obeying the publication limits, the author could not explore all recognized research topics. Nevertheless, in addition to the continuing search for examples of USBMs in various sectors of the Polish economy, it is worth indicating a multi-context discussion on similar business models. For instance, the context of transparency of value chains or the measurable sustainability of the value co-created by various stakeholders could be analyzed. Another interesting idea might be, for example, researching the possibility of creating similar initiatives by local governments or local communities. 


\section{References}

1. Aagaard A. (ed.) (2019), Sustainable Business Models: Innovation, Implementation and Success, Palgrave MacMillan, London.

2. Abdelkafi N., Tauscher K. (2016), Business Models for Sustainability from a System Dynamics Perspective, "Organization \& Environment", Vol. 29(1). DOI: 10.1177/1086026615592930.

3. Agwu U., Bessant J. (2020), Sustainable Business Models: A Systematic Review of Approaches and Challenges in Manufacturing, "Revista de Administracao Contemporanea", Vol. 25(3). DOI: 10.1590/1982-7849rac2021200202.en.

4. Barth H., Ulvenblad P., Ulvenblad P.-O., Hoveskog M. (2021), Unpacking Sustainable Business Models in the Swedish Agricultural Sector - The Challenges of Technological, Social and Organizational Innovation, "Journal of Cleaner Production", Vol. 304. DOI: 10.1016/ j.jclepro.2021.127004.

5. Bocken N., Short S.W., Rana P., Evans S. (2014), A Literature and Practice Review to Develop Sustainable Business Model Archetypes, "Journal of Cleaner Production", Vol. 65. DOI: 10.1016/j.jclepro.2013.11.039.

6. Evans S., Vladimirova D., Holado M., Van Fossen K., Yang M., Silva E.A., Barlow C.Y. (2017), Business Model Innovation for Sustainability: Towards a Unified Perspective for Creation of Sustainable Business Models, "Business Strategy and the Environment", Vol. 26. DOI: 10.1002/bse.1939.

7. Garetti M., Taisch M. (2012), Sustainable Manufacturing: Trends and Research Challenges, "Production Planning \& Control", Vol. 23(2-3). DOI: 10.1080/09537287.2011.591619.

8. Geissdoerfer M., Bocken N., Hultink J. (2016), Design Thinking to Enhance the Sustainable Business Modelling Process - A Workshop Based on a Value Mapping Process, "Journal of Cleaner Production", Vol. 135. DOI: 10.1016/j.jclepro.2016.07.020.

9. Geissdoerfer M., Vladimirova D., Evans S. (2018), Sustainable Business Model Innovation: a Review, "Journal of Cleaner Production", Vol. 198. DOI: 10.1016/j.jclepro.2018.06.240.

10. Goni F., Chofreh A.G., Orakani Z.E., Klemes J.J., Davoudi M., Mardani M. (2020), Sustainable Business Model: A Review and Framework Development, "Clean Technologies and Environmental Policy", Vol. 23. DOI: 10.1016/j.jclepro.2020.121201.

11. Hayes R., Kyer B., Weber E. (2015), The Case Study Cookbook, https://web.wpi.edu/Pubs/ E-project/Available/E-project-121615-164731/unrestricted/USPTO_CookbookFinal.pdf (accessed: 26.06.2021)

12. https://marketingibiznes.pl/biznes/ubrania-do-oddania-sprawily-ze-15-ton-ubran-dzienniewraca-do-obiegu-zamiast-trafiac-na-smietnik/ (accessed: 26.06.2021).

13. https://pl.linkedin.com/company/ubrania-do-oddania (accessed: 26.06.2021).

14. https://www.green-news.pl/1888-startup-ubrania-do-oddania-finansowanie (accessed: 26.06.2021).

15. https://www.pb.pl/ubrania-do-oddania-pomagania-i-zarabiania-986539 (accessed: 26.06.2021).

16. https://www.ubraniadooddania.pl/ (accessed: 26.06.2021).

17. Ludeke-Freund F. (2010), Towards a Conceptual Framework of Business Models for Sustainability, ERSCP-EMU Conference, Delft, The Netherlands.

18. Patala S., Jalkala A., Keranen J., Vaisanen S., Tuomien V., Soukka R. (2016), Sustainable Value Proposiotions: Framework and Implications for Technology Suppliers, "Industrial Marketing Management", Vol. 59. DOI: 10.1016/j.indmarman.2016.03.001.

19. Porter M.E. (1985), The Competitive Advantage: Creating and Sustaining Superior Performance, Free Press, New York.

20. Schaltegger S., Hansen E., Ludeke-Freund F. (2015), Business Models for Sustainability: Origins, Present Research, and Future Avenues, "Organization \& Environment”, Vol. 29(1). DOI: $10.1177 / 1086026615599806$. 
21. Seroka-Stolka O., Surowiec A., Pierasieński P., Dunay A. (2017), Sustainable Business Models, "Zeszyty Naukowe Politechniki Częstochowskiej. Zarządzanie", nr 27(2). DOI: 10.17512/znpcz.2017.3.2.11.

22. Stubbs W., Cocklin C. (2008), Conceptualizing a "Sustainability Business Model", "Organization \& Environment", Vol. 21(2). DOI: 10.1177/1086026608318042.

23. Yip A., Bocken N. (2018), Sustainable Business Archetypes for the Banking Industry, "Journal of Cleaner Production", Vol. 174. DOI: j.jclepro.2017.10.190.

\section{W POSZUKIWANIU KOMPLEKSOWO ZRÓWNOWAŻONEGO MODELU BIZNESU}

Streszczenie: Koncepcja zrównoważonego modelu biznesowego (SBM) okazała się jednym z najbardziej przekonujących tematów badawczych we współczesnym zarządzaniu. Różnorodność obszarów dyskusji i problemów związanych z tworzeniem, wdrażaniem i modyfikowaniem małych i średnich firm oferuje ogromny potencjał badawczy. Celem artykułu jest przedstawienie przykładu SBM, który jest ostateczny, co oznacza, że jest zrównoważony we wszystkich trzech wymiarach, tj. w kontekście technologicznym, społecznym i środowiskowym, poprzez zastosowanie innowacji odpowiadających tym kategoriom (technologicznym, społecznym i organizacyjnym). Szczególną uwagę zwrócono na dyskusję na temat archetypów SBM oraz ram opisujących kluczowe cechy SBM, które posłużyły jako punkty odniesienia dla dalszych badań. Struktura artykułu składa się z dwóch zasadniczych części: po przedstawieniu koncepcji zrównoważonego modelu biznesowego następuje prezentacja wyników badań własnych. Część teoretyczna zawiera prezentację najważniejszych definicji SBM omawianych w literaturze menedżerskiej. W drugiej części, empirycznej, opartej na źródłach wtórnych, opracowano i omówiono ilustracyjne studium przypadku ostatecznie zrównoważonego modelu biznesowego (USBM).

Słowa kluczowe: modele biznesu, zrównoważone modele biznesu, zrównoważona wartość 